\title{
CAMK2B wt Allele
}

National Cancer Institute

\section{Source}

National Cancer Institute. CAMK2B wt Allele. NCI Thesaurus. Code C104831.

Human CAMK2B wild-type allele is located within 7p14.3-p14.1 and is approximately 117 $\mathrm{kb}$ in length. This allele, which encodes calcium/calmodulin-dependent protein kinase type II subunit beta protein, is involved in calcium signaling and neuron function. 